Carlos Fonseca - Ela Varošanec

\title{
Put na jug
}

1.

Na trenutke, u tišini nastanjenoj krajolikom, jedino što se može čuti jest bljeskalica fotografskog aparata. U tom kratkom trenutku postoje samo on, kamera i kadar koji će ostati zabilježen za budućnost koju još ne zna, ali na tu je kartu stavio sve. Samo u tom kratkom trenutku ne postoji ništa osim njega i njegove vjere. Njega i njegove budućnosti. Potom ga, suptilno, prekida ona kratka zvučna katastrofa koja ga vraća natrag u prašumu: tropska šuma koja ječi i vrije u pozadini, kakofonija ptica, graja slobodnih kokoši, hrkanje umornog Indijanca, štucanje pijanog Engleza. Još dalje, na grozno jedinstvenom i bolnom mjestu, jecaji kćeri čije jauke tek sada ponovno čuje.

Tek tada odvaja oči od kamere i pogleda je.

Jedva joj je deset godina, pogled težak od nesanice i strašno bljedilo koji ga podsjete na one nordijske širine koje nikada nije posjetio. Pokraj djevojčice, žena zasljepljujuće ljepote, lijevom rukom čiji oblik i predobro poznaje, umiruje jecaje djevojčice. Drugom rukom, njegova se supruga trudi zapisati bilješke u malenu bilježnicu od crvenkaste kože. U istu onu bilježnicu u koju je prije deset dana napisala: „Prvi dan, početak putovanja.“ Deset dana prošlo je od tog prvog susreta, a putovanje već postaje dugo, teško, zapada u rutinu. Deset dana otkako ih je oronuli autobus ostavio na ulazu u ono što se sada usuđuju zvati prašumom, ali što ponekad izgleda tek kao golemo smetlište iz sna odsutnog boga.

Glasno roktanje svinje koja ponovno počinje kopati po smeću iznova mu odvlači pozornost. Tek tada pogledom obuhvati cijeli prizor: par pijanih Britanaca koji u kutu dovršava bocu zlatnog ruma, atmosfera letargije i sieste nad kojom kao da se nadvija svakodnevna tiranija prirode, drogirani Nijemac koji opet izvodi svoj kazališni monolog za skupinu domorodaca koja, čini se, uz smijeh uživa u predstavi. Usred te kratke komedije, ostali hodočasnici mjestimično zauzimaju scenu dok se odmaraju pod malim limenim nadstrešnicama po kojima monotono tamburaju posljednje kapi vode. A još dalje, u drugom planu koji nagovještava blaga pozadinska buka, klonuo čovjek 
umornog pogleda iznova započinje svoju nerazumljivu molitvu. Prošlo je deset dana otkako im je taj isti muškarac, promukla glasa i neodredivog naglaska, obećao da će potkraj mjeseca vidjeti malenog vidjeoca.

2.

Zovu ga apostolom. Na rukama ima tetovaže alegorija rata, a oko vrata mu visi tucet plastičnih krunica. Glas mu je hrapav, ali tih. Njegov govor pomalo nalikuje deliričnom monologu, toj osobnoj i beskonačnoj molitvi kojom ispunjava prazne sate. Dovoljan je jedan pogled i znaš da nije odavde. Prokleti gringo, tako ga iza leđa zovu domoroci, a on im se odbija obratiti. Pa ipak, kamo god da krene prati ga njih petero. Priča se da je došao u potrazi za drogom i ostao shvativši da se ne može vratiti. Priča se da dolazi iz imućne obitelji i da je u mladosti obećavao kao glumac. Priča se da je doživio prosvjetljenje prije mnogo godina, usred prašume, ispred tog golemog stabla prema kojem kaže da ih vodi. Zovu ga apostolom jer se sam tako nazvao, kao da je tek sredstvo, kao da je tek vodič. Ništa više. Zovu ga apostolom, ali ponekad, promatrajući ga, hodočasnici imaju osjećaj da je tek turistički vodič, drogirani Vergilije u središtu apsurdnog hodočašća. Postmoderni Vergilije za lakovjerne gringose. Ipak, dovoljno je da ga čovjek ponovno pogleda, ili tek čuje, onako utonulog u vječitu molitvu, da bi uvidio da on zaista vjeruje u sve što im je obećao. Oko njega tri smrdljive svinje glavinjaju blatom, dok malo dalje domoroci kartaju kako bi pobijedili dosadu. Svi u majicama sjevernoameričkih robnih marki i s ironičnim pogledom nevjernika. Zovu ga apostolom zato što obećava stvari. Prije deset dana obećao im je, na primjer, da će potkraj mjeseca stići do golemog arhipelaga usred prašume i da će im tamo, u podnožju golemog srušenog stabla, vidjelac pokazati put. U njegovu pogledu, na pola puta između vjerovanja i ludila, cijelo jedno doba odigrat će svoju kartu.

Prošlo je deset dana otkako su pješice krenuli na put. Pet otkako je djevojčica počela pobolijevati. Od tada, prašuma je samo proturječila njihovim očekivanjima. Tamo gdje su očekivali gole domoroce, pronašli su ljude odjevene u majice američkih rock grupa. Tamo gdje su očekivali bujnu prirodu, pronašli su smetlišta. Tamo gdje su očekivali odsutnost vlasti, pronašli su sveprisutnost Države. Gdje god pošli nailaze na policiju, ozbiljne granične policajce koji im pomno pregledavaju putne isprave kako bi pobijedili dosadu. Daleko od toga da bude sanjani vrt, prašuma se trudi pokazati im svoje modernije lice: oronulo lice pograničnog grada. 
Pa ipak, dobro to znaju: priroda je tamo, pritajena poput usnulog škorpiona. Osjećaju je u noćima, u potpunoj tmini koja ih obavija. Čuju je prije nego što je ugledaju: u šuštanju noćnih životinja, u lepetu krila, u kreketu žaba koje se doimaju poput noćnih ptica. Osjećaju je prije nego što je ugledaju: neizdrživi ubodi komaraca koji na koži ostavljaju biljege u obliku roskastih mrlja, zujanje kukaca uvijek spremnih krenuti u boj s mrežicom protiv komaraca. Njega su, ipak, doveli upravo zato da prirodu učini vidljivom: tražili su ga da, kao fotograf, dokumentira putovanje. To je njegovo mjesto: na pola puta između sudjelovanja i promatranja, na pola puta između vjere i ironije. Prije jedva pet godina zarađivao je za život fotografirajući najtraženije modele Broadwayja. Danas slijedi čovjeka koji im je obećao nemoguće. Prije dvije godine zarađivao je za život portretirajući najviđenije figure latinoameričke politike, danas prati trag nevidljivog sna drogiranog gringa.

3.

Danju prolaze selima punim usnulih domorodaca i žena koje krate sate beskonačnim razgovorima. Selima izgubljenim usred prašume, upletenim u klupko čamotinje. Besanim selima u kojima in muškarci tek gledaju kako prolaze, potpuno nezainteresirani, kao da je već prošlo mnogo vremena otkako su hodočasnici postali nevidljivi. Nezainteresiranost, njihov osobni oblik prijezira. Prolaze kroz cijela sela u kojima pronalaze tek ruševine tog mira za kojim su, kako su vjerovali, u potrazi. Trećeg dana shvaćaju da su tim zaboravljenim gradovima vlada čamotinja. U njima mir proizlazi iz prizora majke koja grozničavo krati sate trijebeći uši iz kose desetaka pospane djece. Prolaze čamotnim prizorima, raspoznatljivim korakom onih koji još uvijek nešto traže. Domoroci ih raspoznaju i propuštaju uz podrugljiv pogled. Tako provode dan, lutajući od sela do sela, sve dok popodne ne naiđu na selo gdje su pijanci veseliji, a čamotinja popušta čim dođe poslijepodne. Kroz ta sela propuštaju ih s pohlepom u očima jer znaju da, na kraju krajeva, ti strani ljudi donose novac. A onda počinje dar-mar, policajac se prene iz svoje pijane tuposti, pojavljuje se na sceni i traži dokumente. Lokalni policajac koji se prene iz svoje kronične letargije samo s jednom idejom na pameti - da stane na put tim stranim ljudima. Apostola, ipak, ne dira. I to je ono čudno. Način na koji, čak i u ovim domorodačkim selima, apostol zrači nekom aurom koja ga čini nedodirljivim. Svi pokazuju dokumente a potom on, nedodirljiv i drevan, stupa na scenu kao da poglavica domorodaca. Stupa na scenu, potom prođe selom i nestaje, dok se ostatak hodočasnika ponovno okreće svojim vulgarnijim navadama, alkoholu ili drogi, jogi ili molitvi, snu ili seksu. 
I tako prolazi dan, sve dok, u sumrak, apostol ne izroni iz svoje pokore i napokon ga ugledaju kako diže glas u molitvi. Obično ga prati neka Indijanka, mnogo mlađa od njega, koja hrani vatrene arabeske. I tamo, oko noćne vatre, okupljaju se svi, u iščekivanju da apostol izgovori svoje prve riječi. Ponekad prođu sati. Duge minute u kojima muškarac odbija izgovoriti i riječi i u kojima se čuju tek moljci kako lete oko vatre. Ponekad prolaze sati a da ne kaže ni riječ, ali oni ostaju tamo, ujedinjeni u neuhvatljivoj vjeri, okupljeni oko vatre nepoznate im strasti. Tvore neobičnu skupinu. Drogirani Europljani, Amerikanci obrijanih glava, Europljanke dugih pletenica koje se radosno smiješe kada ugledaju domoroce kako prolaze, mlade djevojke čija lica ocrtavaju tragove umorne iluzije. Rasparane majice, poneko oslikano lice, plastične krunice i svijeće sa slikama svetaca. Velika sekta umornih muškaraca, lakovjernih hipija, koji se u sumrak okupljaju u besanoj zemlji kako bi maštali o drukčijem svijetu. I ondje, među smrdljivim svinjama i usred smeća trećeg svijeta, stoje oni: obična obitelj izgubljena u labirintu vjere. Obična obitelj - otac, majka, kći - izgubljeni u beskrajnoj prašumi koja se ponekad ni ne doima kao prašuma, iščekaju molitvu čovjeka na čijim je rukama tetovirana nedovršena priča, priča o kataklizmama i vatrama, o golemom stablu usred lažnog krajolika. Unatoč tome, oni vjeruju. I ta ih vjera tjera da pričekaju još malo, da traže ključ tog suludog monologa koji apostol ponavlja dan za danom, čim sumrak otvori put noći.

Tamo su oni, obitelj s razglednice, raskošna, iz časopisa, upisana nasred prašume. Baš oni, isti oni koji su se prije pet godina pojavljivali u modnim časopisima, isti oni koji su potom odlučili pozirati u revolucionarnim časopisima, isti oni koji su se jednog dana odlučili otarasiti slave kako bi ušli u labirint poganskih vjerovanja. Uspjeli su se otarasiti slave, utonuti u anonimnost koju osigurava prašuma, ali nisu se uspjeli riješiti onog drugog sloja, mnogo primitivnijeg: ljepote. Zbog toga, dok hodočasnici stoje oko vatre i iščekaju apostolove riječi, tihi kao netko tko se utiša da bi čuo proročanstvo, oni blistaju poput najsjajnijih zvijezda u blijedoj konstelaciji. Lijepa obitelj, ogledna obitelj, uronjena u svijet sumraka.

Možda upravo zato, kada progovori, apostol prvo pogleda njih. Kaže neku blagu riječ koju pušta da visi u zraku i ponovno spusti pogled na djevojčicu kestenjaste kose i tamnih očiju koja opet zakašlje dok se naginje, prirođenom joj sramežljivošću, iza majčinih leđa. Djevojčica posjeduje krhku eleganciju svoje majke i tihu odlučnost svojeg oca. I tako, gledajući tu djevojčicu koja se pokušava sakriti majci iza leđa, gledajući je kao da su njegove riječi namijenjene upravo njoj, 
apostol započinje propovijed. Golim je torzom okrenut prema plamenu, i dok vatra osvjetljava njegova impozantna tetovirana prsa, govori o oluji kraja usred prašume, o vihoru kraja koji će cijeli svijet svesti na jednu točku. Govori o kraju i citira, rječitošću tako različitom od njegove uobičajene tišine, svete knjige. Najzad odvaja pogled od djevojčice i pogleda fiksirana na vatru govori o otocima i ograničenjima, o podzemnom svijetu i tisućljetnim katastrofama. Potom se vraća svojoj molitvi, dok oko njega hodočasnici pažljivo slušaju, potpuno uronjeni u vjerovanje koje, čini se, guta sve pred sobom. U molitvi govori o golemom srušenom stablu i o malenom vidjeocu a lice mu postaje neuobičajeno izražajno, na njemu se ocrtava neka užasna radost koja nalikuje ludilu. Potom mu Indijanka koja je s njim provela popodne donosi malenu staklenku iz koje apostol nešto popije. Nakon nekoliko minuta njegove oči gube oštrinu, a pogled mu odluta onkraj vatre. Tek tada započinje njegov smijeh, gromoglasan smijeh koji odzvanja u noći. Vidjevši ga kako se smije, smiju se i hodočasnici. Smiju se onako kako se ljudi rijetko smiju, bez razloga i smjera, dok noć raste, zastrašujuća, hladna, daleka, oko desetogodišnje djevojčice koja ponovno zakašlje poput nekog tko prekida zabavu.

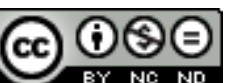

Creative Commons Attribution-NonCommercial-NoDerivatives 4.0 International License 